\title{
Influence of Seed Priming Techniques on Seedling Establishment and Yield of Asparagus Hybrids ${ }^{\dagger}$
}

\author{
Nadiya Shevchenko ${ }^{1, *}$, Olga Lialiuk ${ }^{2}$, Tamara Stribul ${ }^{1}$ and Tetiana Ivchenko ${ }^{2} \mathbb{D}$ \\ 1 Institute for Problems of Cryobiology and Cryomedicine, National Academy of Sciences of Ukraine, \\ 61016 Kharkiv, Ukraine; cryo@online.kharkov.ua \\ 2 Institute of Vegetable and Melon Growing, National Academy of Agrarian Sciences of Ukraine, \\ 62478 Kyiv, Ukraine; merefa4net@gmail.com (O.L.); tanivchenko@ukr.net (T.I.) \\ * Correspondence: nadiyashevchenko79@gmail.com \\ + Presented at the 1st International Electronic Conference on Plant Science, 1-15 December 2020; Available \\ online: https://iecps2020.sciforum.net/.
}

check for updates

Citation: Shevchenko, N.; Lialiuk, O.; Stribul, T.; Ivchenko, T. Influence of Seed Priming Techniques on Seedling Establishment and Yield of Asparagus Hybrids. Biol. Life Sci. Forum 2021, 4, 31. https://doi.org/ 10.3390/IECPS2020-08734

Academic Editor: Yoselin

Benitez-Alfonso

Published: 1 December 2020

Publisher's Note: MDPI stays neutral with regard to jurisdictional claims in published maps and institutional affiliations.

Copyright: (C) 2020 by the authors Licensee MDPI, Basel, Switzerland. This article is an open access article distributed under the terms and conditions of the Creative Commons Attribution (CC BY) license (https:// creativecommons.org/licenses/by/ $4.0 /)$.

\begin{abstract}
Stimulating and increasing of seed field germination, activating the growth of the root system and enhancing productivity is the actual tasks can be solved by priming the seeds of $A s$ paragus officinalis $\mathrm{L}$. The aim of the research was to determine the influence of low-temperature and hydropriming, succinic acid and microelement solution treatment on germination energy, seed germination and quality of planting material of asparagus hybrids. Samples of asparagus hybrids varying by years of reproduction were cooled to temperatures of -70 or $-196{ }^{\circ} \mathrm{C}$ and heated on air at $22{ }^{\circ} \mathrm{C}$ or soaked for $24 \mathrm{~h}$ in water in solutions of microelements according to Murashige and Skoog (1-3 mg/L) and/or succinic acid (1-3 mg/L). The use of low-temperature treatments increased seeds germination. Yield study of growing asparagus seedlings obtained from seeds cooled to $-70{ }^{\circ} \mathrm{C}$ showed a higher number of shoots and roots, their weight compared with the control after 120 days cultivation. Hydropriming of seeds and its further cultivation at optimal temperature conditions promoted significantly higher indices of emergence of asparagus seeds compared to the control values. Treatment of the seeds with microelements and succinic acid did not affect the studied indices after cultivation. It can be concluded that to improve the qualities of asparagus seeds hybrid pretreatment at low temperatures $\left(-70^{\circ} \mathrm{C}\right)$ or hydropriming should be used.
\end{abstract}

Keywords: asparagus officinalis; priming; low temperatures

\section{Introduction}

Effective seed germination is of great importance in agriculture. Rapid and uniform seedling emergence is the basic requirement to increase crop yield and quality. Improving seed vigor is a primary objective of the industry seed production to enhance the critical and yield-defining stage of crop establishment. Low vigor of seeds or adverse environmental conditions after sowing may cause a slow seed germination and unreliable seedling emergence in the field. Seed quality will determine the possibility of producing healthy seedlings and sufficient plant population for achieving a high yield [1]. Pre-sowing seed treatment improves their performance by enhancing the rate of germination and emergence uniformity that results in better and faster development of seedling. Several seed priming techniques have been developed to improve seed germination and seedling growth, plant stress tolerance. Seeds can be treated with different chemicals, ions, organic compounds, hormones, and antioxidants, that stimulates physiological, biochemical, physical agents, and molecular mechanisms that are involved at the early stages of germination. It can induce abiotic stress tolerance mechanisms that improve growth during and after seedling establishment. Effective seed germination is of great importance in agriculture. The rapid and uniform seedling emergence is the basic requirement to increase crop yield and qual- 
ity [2]. The traditional techniques are comprised of hydro-, osmo-, nutrient-, chemical-, bio-priming, seed priming with plant growth regulators or plant extracts.

Hydropriming is a simple and economical technique in which seeds are soaked in water for a specific period and dried to a certain moisture level before sowing [3].

Recently, the priming of seeds in different micronutrient solutions is used to increase the micronutrient availability for plants and their final assimilation in the seed that improved the performance of different field crops [4-6].

Exposure of plants to biotic stress results in an effective induction of numerous defense mechanisms, involving a vast redistribution within both primary and secondary metabolisms. For instance, an alteration of tricarboxylic acid levels can accompany the increase of plant resistance stimulated by various synthetic and natural inducers [7].

The magnetic field, UV radiation, gamma radiation, $\mathrm{X}$-rays, microwaves and heat treatment (low or high temperatures) are some of the physical agents that are used for seed priming [8]. It is known that freezing of seeds is a stage of their stratification. Moreover, freezing seeds to ultra-low temperatures is a necessary condition for their long-term storage [9-12].

Asparagus (Asparagus officinalis) production is of great socio-economic importance. Thus, in 2016, it reached 16.4 million tons worldwide [13]. Asparagus is well known for its organoleptic characteristics and its wealth of nutrients and bioactive compounds. Thus, it was reported as the plant with the highest content of antioxidant compounds among the vegetables commonly consumed in the United States and Europe. The main bioactive compounds in asparagus are phenolics, including phenolic acids and flavonoids, besides important nutrients such as ascorbic acid and glutathione. The nutrients and phytochemicals in asparagus may act as health promoters capturing free radicals, preventing cell oxidation and heart disease and certain cancers [14]. In Ukraine, asparagus is grown on very small areas compared to other countries around Europe. The most important agriculture aspect of asparagus is the quality of the seedlings; they depend on the percentage of rooting after planting and are very important for future crop quality. In this regard, the aim of this research was to determine the influence of deep freezing, hydro- and nutrient priming on seed germination and yield of asparagus hybrids.

\section{Experiments}

Asparagus seeds of Apollo, Atlas, WB-210 hybrids varying by years of reproduction were used in this experiment. They were stored at uncontrolled temperature conditions $\left(8-25{ }^{\circ} \mathrm{C}\right)$ in closed vessels. Seeds were primed by soaking for $24 \mathrm{~h}$ at $22{ }^{\circ} \mathrm{C}$ in water (standard), in solutions of microelements according to Murashige and Skoog [15] (mMS) (1-3 mg/L) or/and succinic acid (SA) (1-3 mg/L). Samples of Atlas and WB-210 hybrids 2015 reproduction (with moisture content of seeds did not exceed 10\%) were frozen in $1.8(\mathrm{~S})$ and 50 (L) $\mathrm{ml}$ polypropylene centrifuge containers (cryovials) down to -70 or $-196{ }^{\circ} \mathrm{C}$ for 2 days and then heated on air at $22{ }^{\circ} \mathrm{C}$ and were sown after 4 days. The dry seeds without any treatment served as a control.

To determine the laboratory germination the seeds were sowed in Petri dishes on moistened with water filter paper and were placed into a cultural chamber at a temperature of $26-30{ }^{\circ} \mathrm{C}$, humidity $90 \%$. Germination energy was measured after 10 days; germination capacity was done after 21 days of cultivation.

The 2015 reproduction sprouted seeds were planted into cassettes with a cell volume of $90 \mathrm{~cm}^{3}$ filled with a soil mixture (peat + perlite) and cultivation in a film greenhouse. To obtain the planting material of asparagus, the seedlings were planted in soil on 15 June 2019. The density of plants in the experiments was 250 thousand pieces/ha. The method of placing the plants is two-lane, according to the scheme $0.1 \times 0.3 \times 0.5 \mathrm{~m}$. The plants were cared using an inter-row cultivation and manual weeding. The level of soil moisture at the experimental site was maintained at a level of not less than $70 \%$ of the lowest field moisture content using drip irrigation. During the growing season, fertilization of plants with mineral fertilizers was carried out three times according to soil analysis. The counting 
of biometric indices of seedlings of the first year of cultivation was carried out on 29 September 2019.

For measurement, 3 replicates with 100 seeds each were used for all variants of the experiment.

The data were analyzed using one-way ANOVA followed by least significant difference with a $95 \%$ probability level. The results showed significant differences between the control group and the treatment group.

\section{Subsection}

The data showed that the highest germination rates were obtained for the seeds of the Apollo hybrid, i.e., $89.1 \%$ and $93.5 \%$, correspondingly; additional pre-sowing treatment did not change these indices. Hydro- and nutrient priming improved the germination energy and capacity of the Atlas hybrid seed 2018 reproduction, the highest result was obtained for the variant with $\mathrm{mMS} 3 \mathrm{mg} / \mathrm{L}+\mathrm{SA} 3 \mathrm{mg} / \mathrm{L}$ ( $88.3 \%$ and 95.5\%, respectively) (Figure 1). The asparagus hybrids seeds of 2015 reproduction had low indices of germination energy and capacity. Hydro- and nutrient priming of Atlas and WB 210 hybrids seeds 2015 reproduction increased the germination capacity. The highest result was obtained after hydropriming of Atlas (73.7\%) and SA $2 \mathrm{mg} / \mathrm{L}(74.6 \%)$ or mMS $2 \mathrm{mg} / \mathrm{L}+\mathrm{SA} 2 \mathrm{mg} / \mathrm{L}$ $(74.3 \%)$ treatment of WB-210 hybrid seeds (Figure 1).

Apollo, 2018

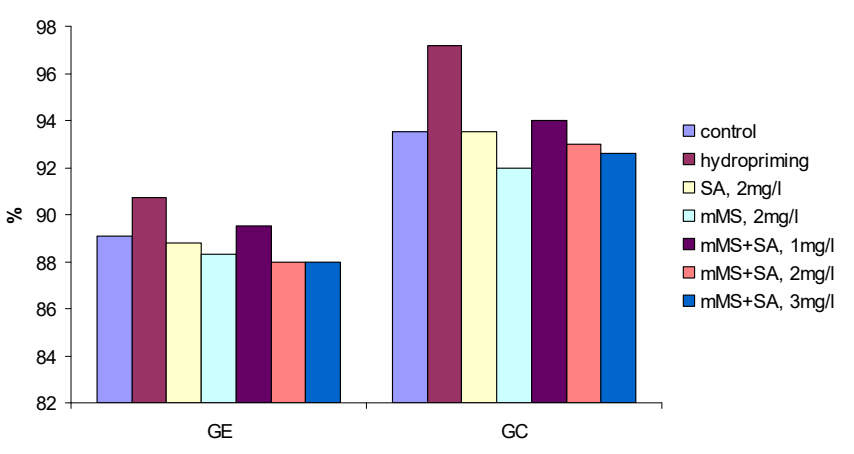

Atlas, 2015

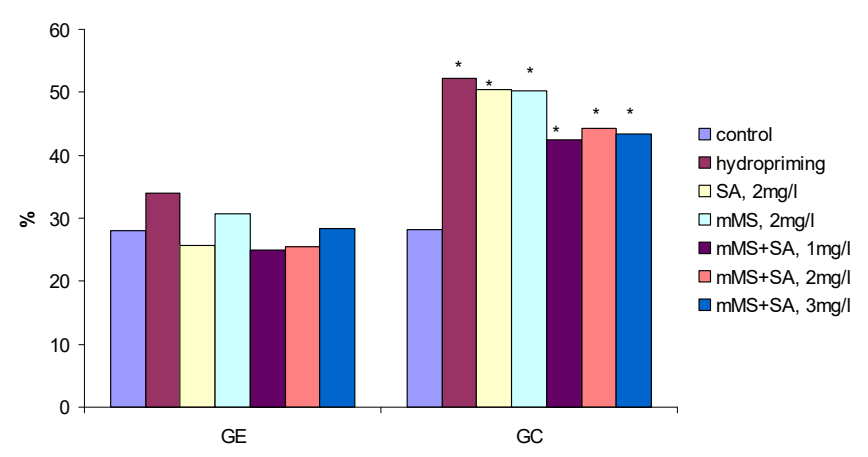

Atlas, 2018

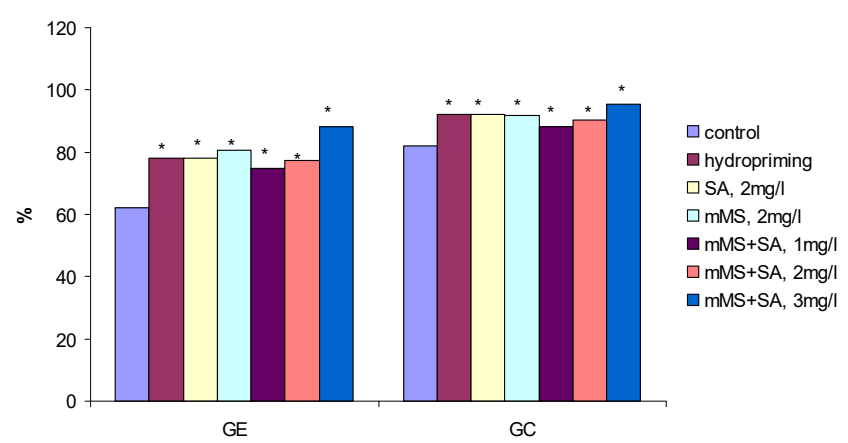

WB-210, 2015

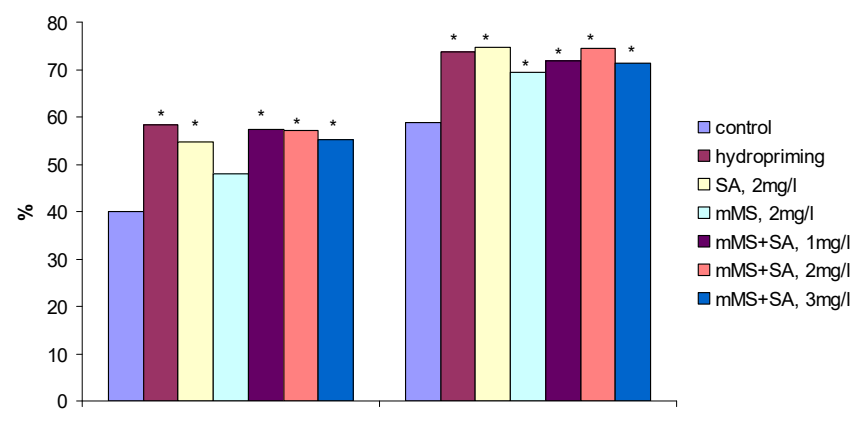

GE

GC

Figure 1. Effect of hydro- and nutrient priming with succinic acid and microelements on germination energy and capacity of asparagus hybrids, (\%): GE—germination energy; GC—germination capacity; * - differences are significant if compared with the control group, $p<0.05$.

The data showed that hydro- and nutrient priming of asparagus seeds generally improved the germination parameters in the laboratory, compared with the control group. We did not obtain a significant increase or decrease in germination rates of seeds after treatment with succinic acid and/or microelements solutions in comparison with hydropriming. 
Therefore, it is impossible to understand what affects the increase in seed germination, in comparison with the control: is this saturation with water or the effect of solutes?

The low-temperature effect on the germination rates was determined for the seeds of 2015 reproduction. This is due to the fact that this batch of seeds had poor sowing characteristics. The data showed that various low-temperature treatments did not affect germination energy of Atlas hybrid seeds 2015 reproduction but increased the germination capacity compared with the control value ( $42.5-50.5 \%$ vs. $28.2 \%)$, especially freezing in $1.8 \mathrm{~mL}$ cryovials to both temperatures. For WB-210 hybrids seeds 2015 reproduction laboratory germination increased for all the variants of cooling on both date of determination (Figure 2).

Atlas, 2015

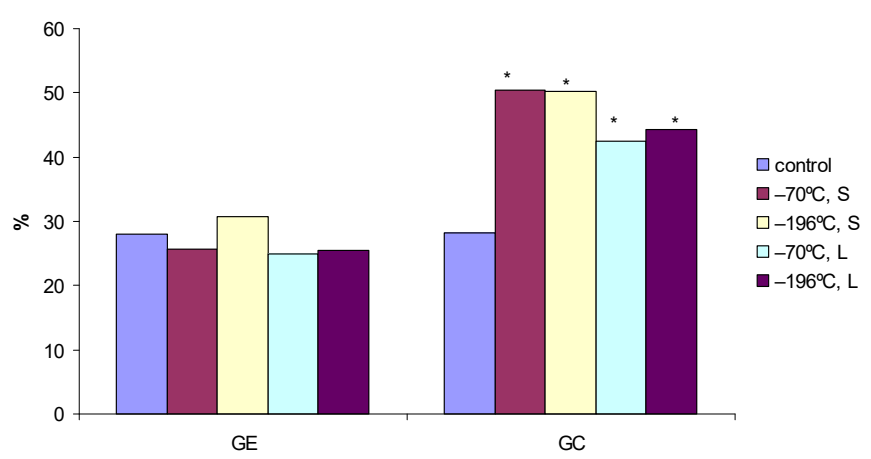

WB-210, 2015

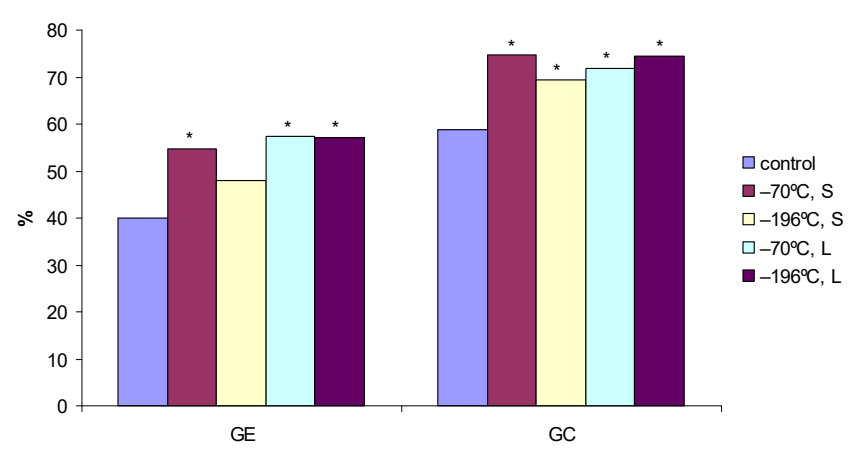

Figure 2. Effect of different low-temperature treatments on germination energy and capacity of asparagus hybrids 2015 reproduction (\%): GE—germination energy; GC—germination capacity; * — differences are significant if compared with the control group, $p<0.05$.

We determined the effect of seeds pretreatment on quality of planting material only for the seeds of 2015 reproduction. This is due to the fact that they had low rates of laboratory germination. It was interesting to know how much seeds priming could improve their productivity.

Yield study of growing the Atlas 2015 seedlings showed increase in shoots' height for all the variants of pretreatment (low temperatures, hydro- and nutrient priming) compared with the control indices (67.3-83.5\% vs. 54.7\%). Increase of shoots number, their weight and roots weight were observed only after low-temperatures treatment down to $-70{ }^{\circ} \mathrm{C}$. The seedlings obtained from the seeds cooled in $1.8 \mathrm{~mL}$ containers showed a bigger number of shoots (18.3), increase weight of shoots (154.4 g) and roots (104.4 g) compared with the control value (11.9 units, 81.0 and $62.0 \mathrm{~g}$ respectively), in case of $50 \mathrm{~mL}$ cryovials shoots number were 16.0, their weight was $139.5 \mathrm{~g}$ and roots weight made $91.6 \mathrm{~g}$. Freezing of seeds in $1.8 \mathrm{~mL}$ cryovials down to liquid nitrogen temperature led to an increase in number of shoots (14.3) and their weight (134.2) (Figure 3).

Hydro- and nutrient priming of asparagus seeds in laboratory generally improved the germination parameters. However, its effectiveness in field almost did not affect the quality of planting material.

Our data indicate that asparagus seeds freezing to $-70{ }^{\circ} \mathrm{C}$ leads to a significant increase in all studied parameters for Atlas and WB-210 varieties 2015 reproduction. When the seeds were frozen to liquid nitrogen temperatures, a significant increase in the quality indices of the planting material was observed only in rapid freezing ( $1.8 \mathrm{~mL}$ cryovials). 

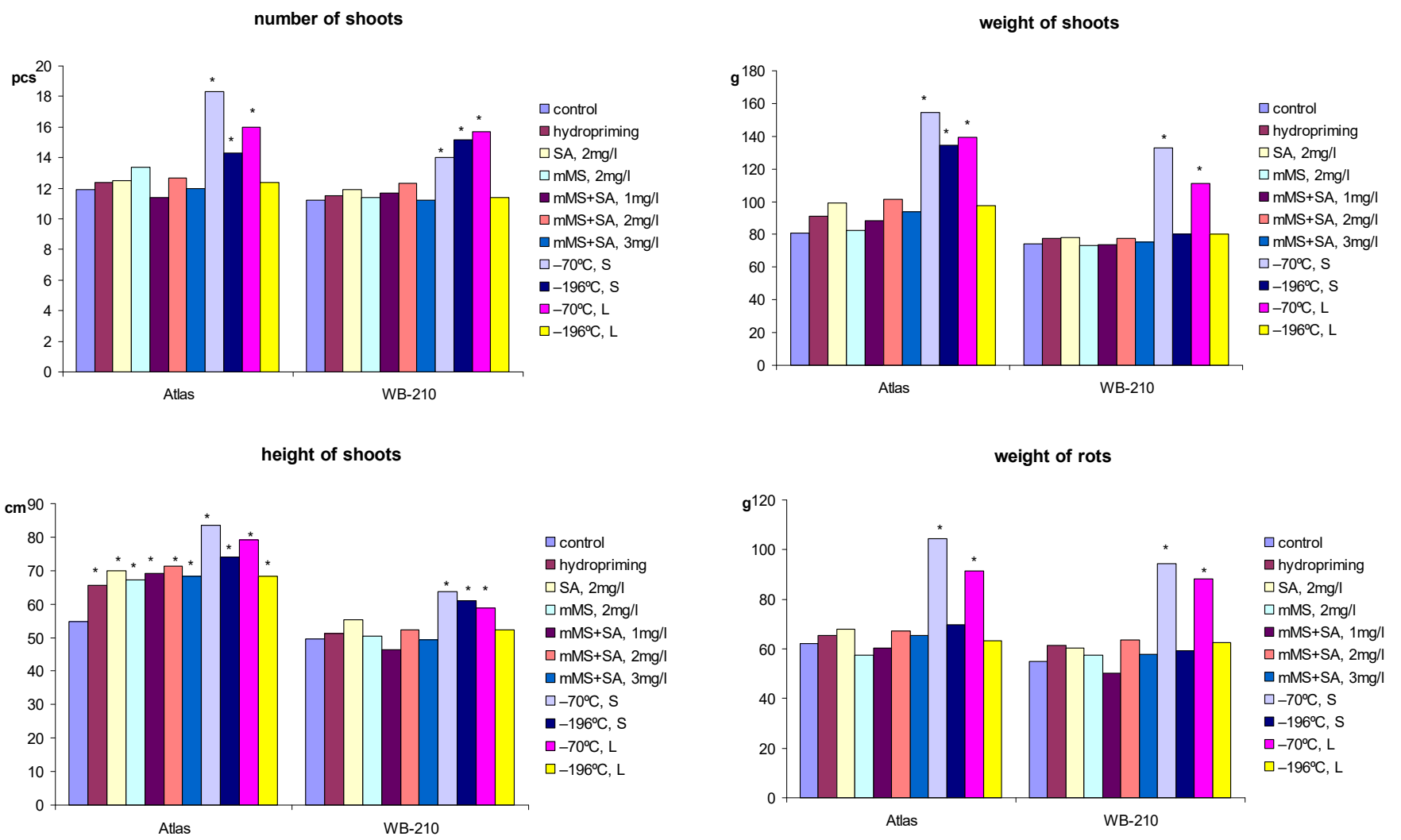

Figure 3. Effect of different low-temperature treatments, hydro- and nutrient priming on development of seedlings of asparagus hybrids 2015 reproduction (\%), ${ }^{*}$ - differences are significant if compared with the control group, $p<0.05$.

\section{Discussion}

Seed priming is a pre-sowing treatment successfully used to improve the germination performance and stable establishment of various cultivated plants in both optimal and adverse environmental conditions. Seed germination begins with the process of water uptake by the mature seed. Besides oxygen and the optimal temperature, the inflow of water to the non-dormant dry seed is the primary event required for the initiation and proper course of germination. Water is necessary for the resumption of metabolic activity since it creates the environment for biochemical reactions, stabilizes the conformation of macromolecules and acts as a reactant in numerous processes. The restoration of metabolic activity, together with appropriate turgor pressure generated by the progressively increasing water content, leads to embryo growth and ultimately to radicle protrusion through the seed coat, which defines the endpoint of germination [16].

Hydropriming can improve radicle emergence, germination rate, seedling vigor, and establishment, as well as yield by making changes in metabolic activities in the seeds of several crops [1,17]. Some studies have confirmed that hydropriming advanced germination of different crop species resulting in higher values of germination parameters and seedling growth, such as germination index [18], germination time [19], and seedling vigor index [20]. Priming promotes germination rate and uniformity due to some kind of metabolic repair of seeds during imbibition, build-up of germination-enhancing metabolites, osmotic adjustment, and a simple reduction in imbibition lag time [1]. The beneficial effects of priming have been observed in several field crops, such as wheat, maize, sugar beet, soybean, sunflower beans, carrot, leek and onion, celery, lettuce, endive, pepper, tomato $[1,21,22]$.

Using a combined transcriptomic and proteomic approach had shown that the background of priming-improved germination was a highly complicated process associated with the up-regulation of genes and proteins involved in cell division, cell wall modification, cytoskeletal organization, oxidative stress response, as well as water transport [23]. 
It should be noted that an improved water uptake during post-priming germination can not be considered as the only factor responsible for the enhanced germination of osmoprimed seeds. It has been found that one of the reasons responsible for the rapid germination of primed seeds is the initiation of germination-related processes during pre-hydration [24], which allows the primed seed to achieve a more advanced metabolic state before germination starts. Kubala et al. [23] suggested that during post-priming germination, the production of proteins related with a faster germination was a direct consequence of preliminary priming. Nevertheless, the authors did not exclude the fact that proteins accumulated during certain germination times of the primed seed may appear later in the unprimed seeds when they would reach a similar water content. Taken together, superior germination of primed seeds is an outcome of many overlapping mechanisms induced by priming, including efficient water absorption which certainly significantly contributes to this effect.

Our data indicate that cryopreservation enhanced germination and yield of asparagus seeds. Similar response was reported for several Ilex species [11], for Pyrus communis [25], Halimium atriplicifolium, Helianthemum apenninum, Helianthemum squamatum [9], Angelica ursina, Oxytropis chankaenis, Oxytropis retusa [10], Passiflora suberosa and Passiflora edulis [26] after seed cryostorage. It has been suggested that liquid nitrogen exposure may enhance the germination of treated seeds by breaking seed dormancy or softening of the seed coat $[10,25]$. In many species, the exposure of seeds to low temperatures decreases the endogen content of abscisic acid and increases the gibberellin and cytokinin levels, which interact in a sequential way to break dormancy [27].

\section{Conclusions}

The data showed that hydro- and nutrient priming of asparagus seeds generally improved the germination parameters under laboratory conditions compared with the control group. We did not receive a significant increase or decrease in germination rates of seeds after treatment with succinic acid and/or microelements solutions in comparison with hydropriming. The obtained results showed that various low-temperature treatments did not affect germination energy of Atlas hybrid seeds 2015 reproduction but increased the germination capacity compared with the control value, especially freezing in $1.8 \mathrm{~mL}$ cryovials to both temperatures. For WB-210 hybrids seeds 2015 reproduction laboratory germination increased for all the variants of cooling on both terms of determination. The data indicate that freezing asparagus seeds to $-70{ }^{\circ} \mathrm{C}$ leads to a significant increase in number, height, weight of shoots and weight of roots for Atlas and WB-210 varieties 2015 reproduction. When the seeds were frozen to liquid nitrogen temperatures, a significant increase in the quality indices of the planting material was observed only in rapid freezing (1.8 mL cryovials). Hydro- and nutrient priming of asparagus seeds almost did not affect the quality of planting material in field.

Author Contributions: N.S. and T.I. conceived and designed the experiments; N.S. and O.L. performed the experiments; T.I. and T.S. statistical data processing and analysis; O.L. contributed reagents, materials and analysis tools; N.S. and T.S. wrote the paper. All authors have read and agreed to the published version of the manuscript.

Institutional Review Board Statement: The study was conducted according to the guidelines of the Declaration of Helsinki, and approved by the Ethics Committee) of Institute for Problems of Cryobiology and Cryomedicine of the National Academy of Sciences of Ukraine (protocol No. 12, on 24 December 2018).

Informed Consent Statement: Informed consent was obtained from all subjects involved in the study.

Data Availability Statement: The data were submitted by the Institute of Vegetable and Melon Growing to the National Academy of Agrarian Sciences of Ukraine e for 2019.

Conflicts of Interest: The authors declare no conflict of interest. 


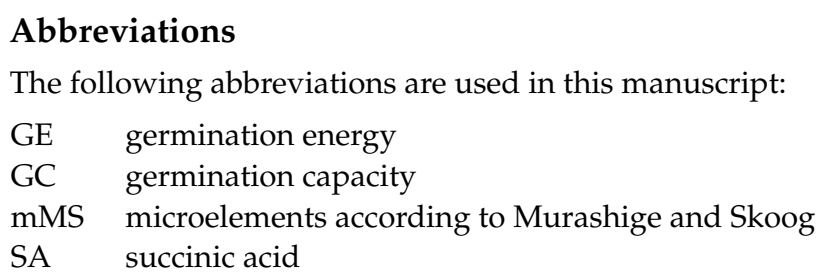

\section{References}

1. Damalas, C.A.; Koutroubas, S.D.; Fotiadis, S. Hydro-priming effects on seed germination and field performance of faba bean in spring sowing. Agriculture 2019, 9, 201. [CrossRef]

2. Ibrahim, E.A.A. Fundamental Processes Involved in Seed Priming. In Priming and Pretreatment of Seeds and Seedlings; Hasanuzzaman, M., Fotopoulos, V., Eds.; Springer: Singapore, 2019; pp. 63-115. [CrossRef]

3. Singh, H.; Jassal, R.K.; Kang, J.S.; Sandhu, S.S.; Kang, H.; Grewal, K. Seed priming techniques in field crops-a review. Agric. Rev. 2015, 36, 251-264. [CrossRef]

4. Ullah, A.; Farooq, M.; Nadeem, A.; Rehman, A.; Asad, S.A.; Nawaz, A. Manganese nutrition improves the productivity and grain biofortification of fine grain aromatic rice in conventional and conservation production systems. Paddy Water Environ. 2017, 15, 563-572. [CrossRef]

5. Iqbal, S.; Farooq, M.; Cheema, S.A.; Afzal, I. Boron seed priming improves the seedling emergence, growth, grain yield and grain biofortification of bread wheat. Int. J. Agric. Biol. 2017, 19, 177-182. [CrossRef]

6. Farooq, M.; Ullah, A.; Rehman, A.; Nawaz, A.; Nadeem, A.; Wakeel, A.; Nadeem, F.; Siddique, K.H. Application of zinc improves the productivity and biofortification of fine grain aromatic rice grown in dry seeded and puddled transplanted production systems. Field Crops Res. 2018, 216, 53-62. [CrossRef]

7. Balmer, A.; Pastor, V.; Glauser, G.; Mauch-Mani, B. Tricarboxylates induce defense priming against bacteria in Arabidopsis thaliana. Front. Plant Sci. 2018, 9, 1221. [CrossRef]

8. Bilalis, D.J.; Katsenios, N.; Efthimiadou, A.; Karkanis, A.; Efthimiadis, P. Investigation of pulsed electromagnetic field as a novel organic pre-sowing method on germination and initial growth stages of cotton. Electromagn. Biol. Med. 2012, 31, 143-150. [CrossRef]

9. Perez-García, F.; Gonzalez-Benito, M.E. Seed cryopreservation of Halimium and Helianthemum species. Cryoletters 2008, 29, 271-276.

10. Kholina, A.B.; Voronkova, N.M. Conserving the gene pool of Far Eastern plants by means of seed cryopreservation. Biol. Bull. 2008, 35, 262-269. [CrossRef]

11. Dolce, N.R.; Medina, R.D.; González-Arnao, M.T. Tolerance to desiccation and cryopreservation of seeds of seven south american Ilex species. HortScience 2018, 53, 882-886. [CrossRef]

12. Pérez, J.; Araya-Valverde, E.; Garro, G.; Abdelnour-Esquivel, A. Analysis of stress indicators during cryopreservation of seeds of landrace maize (Zea mays). Cryoletters 2017, 38, 445-454.

13. Noperi-Mosqueda, L.C.; López-Moreno, F.J.; Navarro-León, E.; Sánchez, E.; Blasco, B.; Moreno, D.A.; Soriano, T.; Ruiz, J.M. Effects of asparagus decline on nutrients and phenolic compounds, spear quality, and allelopathy. Sci. Hortic. 2020, 261, 109029. [CrossRef]

14. Sanae, M.; Yasuo, A. Green asparagus (Asparagus officinalis) prevented hypertension by an inhibitory effect on angiotensinconverting enzyme activity in the kidney of spontaneously hypertensive rats. J. Agric. Food Chem. 2013, 61, 5520-5525. [CrossRef]

15. Murashige, T.; Skoog, F. A revised medium for rapid grown and bioassay with tobacco tissue culture. Physiol. Plant 1962, 15, 473-497. [CrossRef]

16. Lechowska, K.; Kubala, S.; Wojtyla, Ł.; Nowaczyk, G.; Quinet, M.; Lutts, S.; Garnczarska, M. New insight on water status in germinating Brassica napus seeds in relation to priming-improved germination. Int. J. Mol. Sci. 2019, 20, 540. [CrossRef] [PubMed]

17. Paparella, S.; Araújo, S.S.; Rossi, G.G.; Wijayasinghe, M.; Carbonera, D.; Balestrazzi, A. Seed priming: State of the art and new perspectives. Plant Cell Rep. 2015, 34, 1281-1293. [CrossRef]

18. Moreno, C.; Seal, C.E.; Papenbrock, J. Seed priming improves germination in saline conditions for Chenopodium quinoa and Amaranthus caudatus. J. Agron. Crop Sci. 2018, 204, 40-48. [CrossRef]

19. Alias, N.S.B.; Billa, L.; Muhammad, A.; Singh, A. Priming and temperature effects on germination and early seedling growth of some Brassica spp. Acta Hortic. 2018, 1225, 407-414. [CrossRef]

20. Umair, A.; Ali, S.; Bashir, K.; Hussain, S. Evaluation of different seed priming techniques in mung bean (Vigna radiata). Soil Environ. 2010, 29, 181-186.

21. Michalska-Klimczak, B.; Wyszyński, Z.; Pačuta, V.; Rašovský, M.; Różańska, A. The effect of seed priming on field emergence and root yield of sugar beet. Plant Soil Environ. 2018, 64, 227-232. [CrossRef]

22. Singh, V.K.; Singh, R.; Tripathi, S.; Devi, R.S.; Srivastava, P.; Singh, P.; Kumar, A.; Bhadouria, R. Seed priming: State of the art and new perspectives in the era of climate change. In Climate Change and Soil Interactions; Prasad, M.N.V., Pietrzykowski, M., Eds.; Elsevier: Amsterdam, The Netherlands, 2020; pp. 143-170. [CrossRef] 
23. Kubala, S.; Garnczarska, M.; Wojtyla, Ł.; Clippe, A.; Kosmala, A.; Żmieńko, A.; Lutts, S.; Quinet, M. Deciphering priming-induced improvement of rapeseed (Brassica napus L.) germination through an integrated transcriptomic and proteomic approach. Plant Sci. 2015, 231, 94-113. [CrossRef]

24. Soeda, Y.; Konings, M.C.J.M.; Vorst, O.; van Houwelingen, A.M.M.L.; Stoopen, G.M.; Maliepaard, C.A.; Kodde, J.; Bino, R.J.; Groot, S.P.C.; van der Geest, A.H.M. Gene expression programs during Brassica oleracea seed maturation, osmopriming, and germination are indicators of progression of the germination process and the stress tolerance level. Plant Physiol. 2005, 137, 354-368. [CrossRef] [PubMed]

25. Reed, B.M.; Schwanke, S.; Shala, R. Pear seeds retain viability after liquid nitrogen immersion. HortScience 2001, 36, 1121-1122. [CrossRef]

26. Araujo, D.S.; Luz, P.B.; Neves, L.G.; Paiva Sobrinho, S. Seed cryopreservation of Passiflora species. J. Seed Sci. 2016, $38,248-253$. [CrossRef]

27. Bewley, J.D. Seed germination and dormancy. Plant Cell 1997, 9, 1055-1066. [CrossRef] [PubMed] 